\title{
GEOSTATISTICAL HYDROGEOCHEMICAL 3D MODEL FOR KŁODZKO UNDERGROUND WATER INTAKE AREA
}

\author{
PART I. ESTIMATION OF BASIC STATISTICS \\ ON QUALITY PARAMETERS OF UNDERGROUND WATERS
}

\author{
BARBARA NAMYSŁOWSKA-WILCZYŃSKA \\ Institute of Geotechnics and Hydrotechnics, Wrocław University of Technology \\ Wybrzeże Wyspiańskiego 27, 50 - 370 Wrocław, Poland. \\ E-mail: barbara.namyslowska-wilczynska@pwr.wroc.pl
}

\begin{abstract}
The paper presents the first stage of research on a geostatistical hydrogeochemical 3D model dedicated to the horizontal and vertical spatial and time variation in the topographical, hydrological and quality parameters of underground water in the Kłodzko water intake area. The research covers the period 1977-2012.

For this purpose various thematic databases, containing original data on coordinates $X, Y$ (latitude and longitude) and $Z$ (terrain elevation and time - years) and on regionalized variables, i.e., the underground water quality parameters in the Kłodzko water intake area determined for different analytical configurations ( 22 wells, 14 wells, 14 wells +3 piezometers), were created. The data were subjected to spatial analyses using statistical methods. The input for the studies was the chemical determination of the quality parameters of underground water samples taken from the wells in the water intake area in different periods of time. Both archival data (acquired in the years 1977-1999, 1977-2011) and the latest data (collected in November 2011 and in January 2012) were analyzed.

First, the underground water intake area with 22 wells was investigated. Then in order to assess the current quality of the underground water, 14 wells out of the 22 wells were selected for further chemical analyses and a collection siphon wall was included. Recently, three new piezometers were installed in the water intake area and so new water samples were taken, whereby the databases were supplemented with new chemical determinations. The variation in the topographical parameter (terrain elevation) and in the hydrogeological parameters: water abstraction level $Z$ (with and without the land layout being taken into account) and the depth of occurrence of the water table, was examined. Subsequently, the variation in quality parameters was studied on the basis of data coming from 22 wells, then 14 wells and finally from 14 wells and 3 piezometers. The variation in: $\mathrm{Fe}, \mathrm{Mn}$, ammonium ions $\mathrm{NH}_{4}^{+}$, nitrite anion $\mathrm{NO}_{3}^{-}$and phosphate anion $\mathrm{PO}_{4}^{-3}$ content values, total organic carbon (TOC) $\mathrm{C}$ content, the $\mathrm{pH}$ reaction and temperature $\left({ }^{\circ} \mathrm{C}\right)$ of the water was investigated.

The basic statistics and distribution histograms of the topographical, hydrogeological and quality parameters (22 wells, 14 wells, 14 wells +3 piezometers; the years: 1977-1999, 2011, 2011-2012) were estimated and detailed characteristics of the variation in the parameters in the whole underground water intake area over the years were obtained.

Generally, the behaviour of the underground water quality parameters has been found to vary in space and time. Thanks to the multidirectional spatial analyses of the variation in the quality parameters in the Kłodzko underground water intake area some regularities in the variation in water quality have been identified.
\end{abstract}




\section{INTRODUCTION}

The aim of this research was to develop a geostatistical hydrogeochemical 3D model of the variation in the topographical, hydrogeological and quality parameters of underground water in the Quaternary deposits [7], [8], [16], [19] in the water intake area near the town of Kłodzko'. The horizontal and vertical spatial and time variation in the parameters was analyzed on the basis of archival data (1977-1999) for 22 (pump and siphon) wells, later data obtained (November 2011) from tests of water taken from 14 wells and the latest data (January 2012) acquired from three piezometers.

The author's intention was to create a space-time model of the variation in the different quality parameters of the subterranean water, which could be used to determine the spatial characteristics of the parameters [3], [6], [9]-[11], [13]-[15], [20], [23], i.e., estimated averages $Z^{*}$ of the parameters investigated at various points (locations $X, Y$, $Z$ ) within the Kłodzko underground water intake area and also in particular time intervals, which may be of interest to both theoreticians and practitioners (users), e.g., in "the Kłodzko Waterworks".

The data on the chemical analyses of the underground water in the Kłodzko water intake area, carried out for 22 wells in the years 1977-1999 and 1977-2011, were processed and made available by Maria Włodarska, MSc., and Maciej Pluta, MSc., both from "the Kłodzko Waterworks", were inserted in report [22]. Underground water samples were also taken from 14 wells in the water intake area on 15.11.2011 and their chemical analyses were carried out by Dr. Małgorzata Wolska and Izabela Biedroń, MSc., from the Laboratory of the Institute of Environmental Protection at Wrocław University of Technology (WUT) on 20.11.2011.

The data from the three new piezometers (P-1, P-2, P-3) in the Kłodzko underground water intake area were made available by the Poltegor Surface Mining Institute in Wrocław, which had installed the piezometers. The physicochemical properties (26 different parameters) of the underground water samples were determined in the Poltegor Institute Laboratory (on 13.01.2012 and 23.01.2012).

Chemical analyses of the particular quality parameters of the underground water taken from 14 wells located in the Kłodzko water intake area were carried out in the Laboratory of the Institute of Environmental Protection at WUT in accordance with the standards listed in the report from the grant [22]. Also bacterial examinations of the water coming from the wells were carried out [22], but they are not reported here

\footnotetext{
${ }^{1}$ The results presented in this paper have been obtained as part of development research grant NCBiR No. N09-0036 - 10/2011, entitled "The technology of biochemical remediation and storage of surface waters in underground hydrogeological structures for intakes of municipal waters in river valleys", funded by the Ministry of Science and Higher Education in Warsaw. Task 3 is entitled "Identification and hydrogeochemical models of the Kłodzko Catchment (2011-2012)" [22].
} 
because of the limited space of this paper.

Different thematic databases, containing values of coordinates $X, Y$ (latitude and longitude) and $Z$ (terrain elevation) and the topographical, hydrogeological and quality parameters of the underground water, were created. The data in the databases are for water in 22 wells, 14 wells, 14 wells +3 piezometers $=17$ holes and 3 piezometers, located in the Kłodzko water intake area. The contents of the thematic databases formed the basis for spatial (3D) geostatistical analyses carried out for different analytical configurations [22].

This paper presents selected results of the statistical analyses of the variation in the parameters investigated for the Kłodzko water intake area, aimed at determining their statistics and distribution histograms [Part I].

\section{AREA INVESTIGATED AND RANGE OF INVESTIGATIONS}

The data for 22 wells located in the Kłodzko water intake area (Fig. 2.1a) were subjected to spatial analyses. The area in which the wells are located belongs to the Regional Water Management Board and the Kłodzko Waterworks. Currently some of the wells ( 9 wells - the green colour) are active and some of them ( 7 wells - the red colour) are to be closed.

The residents of Kłodzko are supplied with water from the water main based on underground intakes from Quaternary deposits [7], [8], [16], [19]. The water is taken off via dug and bored wells with siphon or pump water collection located on both sides of the Kłodzko Neisse. Work on the water intakes began in the years 1883-1886 when two $10 \mathrm{~m}$ deep (shaft) wells were dug from which water would be siphoned off. The other wells, each $200 \mathrm{~mm}$ in diameter, were sunk after World War II (in the years: 1952, 1974, 1977, 1982-1988, 1999). Generally, the depth of the wells ranged from 9.5 to $38.0 \mathrm{~m}$. From the pump wells water is pumped to an aeration tower. From the siphon wells water goes to a collector well from which it is pumped to the aeration tower. Mainly reduced compounds of Fe and $\mathrm{Mn}$ are oxidized in the aeration tower from which water flows by gravity to reaction reservoirs.

The Kłodzko water intake grounds, owned by the Kłodzko Waterworks Company, have been traditionally divided into two areas:

- area 1 - the "old intake" grounds situated on the left bank of the Kłodzko Neisse, where pump wells 4p, 3 (SIV), 4 (SV) and siphon wells No. I, II, IVa, IVb, V, $\mathrm{IXb}, \mathrm{SI}$ are located;

- area 2 - the "new water-bearing grounds" situated in the bifurcation of the Duszniki Bystrzyca and the Kłodzko Neisse, where wells 6 (SXIba), 7 (SIX), 8 (SX), 9 (SXI), 10 (SXIIba), 11 (SXII) and distribution substations (supplying the pumping engines installed in the wells) are located.

Area 1 is situated in the north part of the water-bearing grounds where the siphon 
wells are located. The area is bounded by the Duszniki Bystrzyca in the south and by the Kłodzko Neisse in the west. The aquiferous layer in the area of well IXb is made of pebbles, gravels and sands. The bottom of the aquifer is located at $18.5 \mathrm{~m}$ below the ground level (well SI) and $21.5 \mathrm{~m}$ b.g.l. (well IXb). The filtration coefficient of the aquiferous layer amounts to $20 \mathrm{~m} / \mathrm{d}$ and the average static water table level reaches $2.0 \mathrm{~m}$ b.g.l.

Area 2 is situated in the south part of the water-bearing grounds in the bifurcation of the Duszniki Bystrzyca and the Kłodzko Neisse. The area is bounded by the Kłodzko Nowe-Kudowa Zdrój railway line in the south, the Duszniki Bystrzyca in the north west and the Kłodzko Neisse in the north east. The roof of the poorly permeable layer lies at a depth from $34.5 \mathrm{~m}$ (near hole XIIIb) to $38 \mathrm{~m}$ (near well XIIIba). The aquifer is made of sands with an admixture of river accumulation gravels and pebbles. The poorly permeable layer is formed by old Palaeozoic greenstone waste. In some places interlayers of poorly permeable silt or sand and gravel with clay interbeddings occur. The filtration coefficient ranged from $14 \mathrm{~m} / \mathrm{d}$ (near hole XIIb) to $33 \mathrm{~m} / \mathrm{d}$ (near holes XIba and XIb). An above-average $\mathrm{Mn}$ and $\mathrm{Fe}$ content was found in the water tapped from the wells. The static underground water table is located at $2.0 \mathrm{~m}$ b.g.l.

In the first stage of the investigations, data from the 22 wells sunk in the years 1954-1998 (Fig. 1a), with intake area elevations in the range of 287.22-297.7 m a.s.l. (at an average elevation of $291.68 \mathrm{~m}$ a.s.l.), were analyzed. The subject of the 3D analyses ${ }^{2}$ was the variation in the various underground water parameters:

- the topographic parameters (terrain elevation - $m$ a.s.1.);

- the hydrogeological parameters: water abstraction level $Z$ (m a.s.l.) - the dynamic water table and the depth of occurrence of the underground water table (m a.s.l.). The dynamic water table is the underground water level with the terrain elevation (landform features) taken into account, after the well is started, i.e., during the operation of the pump, while the water abstraction depth is the difference between the terrain elevation and the dynamic water table level;

- the quality parameters: $\mathrm{Fe}\left[\mathrm{gFe} / \mathrm{m}^{3}\right], \mathrm{Mn}\left[\mathrm{gMn} / \mathrm{m}^{3}\right]$ and ammonium ion $\mathrm{NH}_{4}$ $\left[\mathrm{gNH}_{4}^{+} / \mathrm{m}^{3}\right]$ content values, oxidizing capacity $\left[\mathrm{gO}_{2} / \mathrm{m}^{3}\right]$.

In the second stage of the investigations, data from the 14 wells, and also from the collector siphon well located in the Kłodzko water intake area (Fig. 1a), obtained on 15.11.2011 were analyzed. Spatial analyses of the variation in the different quality parameters, i.e., $\mathrm{Fe}\left[\mathrm{gFe} / \mathrm{m}^{3}\right], \mathrm{Mn}\left[\mathrm{gMn} / \mathrm{m}^{3}\right]$, ammonium ion $\left[\mathrm{gNH}_{4}{ }^{+} / \mathrm{m}^{3}\right]$, nitrite anion $\mathrm{NO}_{3}^{-}\left[\mathrm{gNO}_{3} / \mathrm{m}^{3}\right]$ and phosphate anion $\mathrm{PO}_{4}^{-3}\left[\mathrm{gPO}_{4}^{-3} / \mathrm{m}^{3}\right]$ content values, total organic carbon (TOC) content $\mathrm{C}\left[5 \mathrm{gC} / \mathrm{m}^{3}\right], \mathrm{pH}$ redox potential and temperature ${ }^{\circ} \mathrm{C}$ [degrees], were carried out on the basis of the chemical determinations of water samples.

In January 2012, three new piezometers (P1, P2, P3) were drilled to a depth of $9-10 \mathrm{~m}$ in the Kłodzko water intake area. The piezometer locations had been previ-

${ }^{2}$ The spatial (3D) analyses were carried out using statistical software package ISATIS (version 2012.4) made by Geovariances Firm, Avon Cedex - Fontainebleau, France. 
ously selected in the grounds belonging to the Agricultural Estate Agency, the Re-

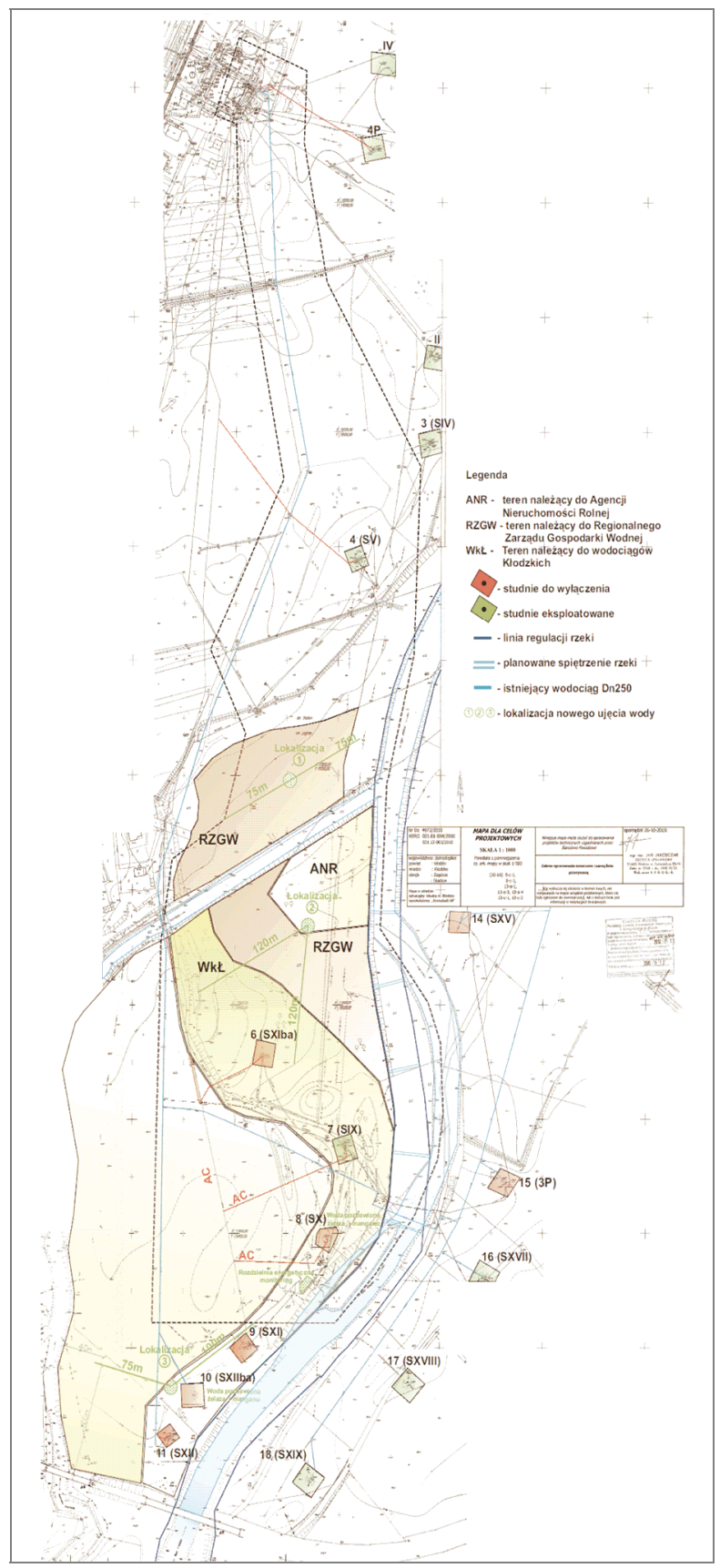


Fig. 1a. Map showing locations of underground wells (wells to be closed - red colour; active wells - green colour) in Kłodzko water intake area (22 wells)

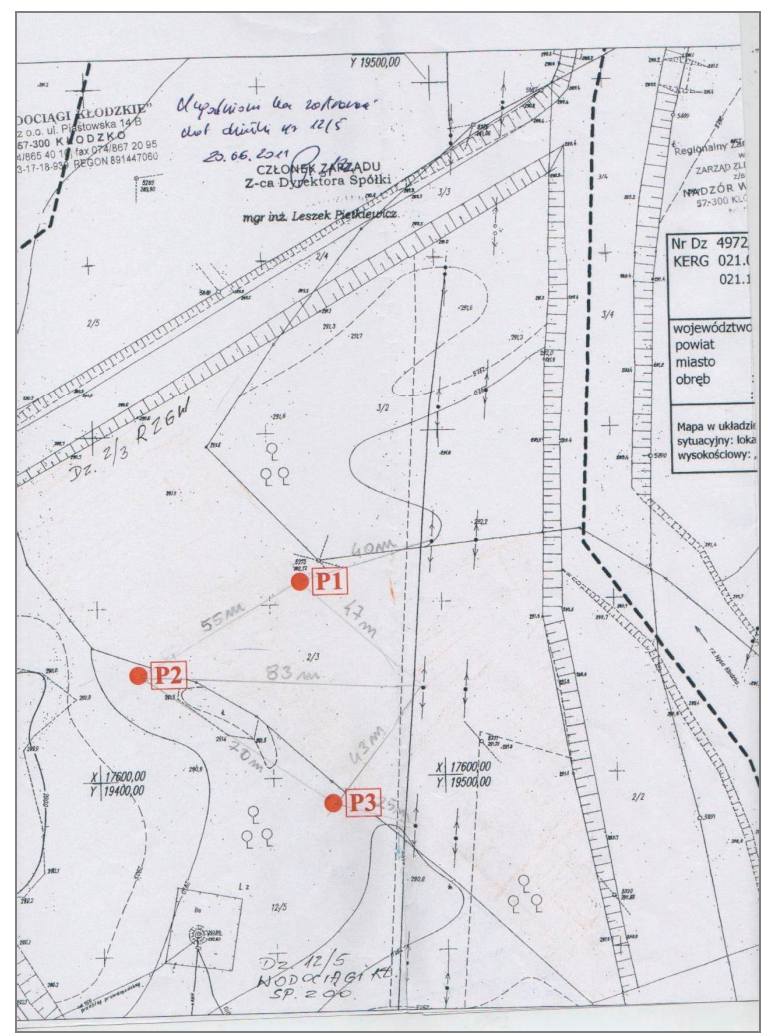

Fig. 1b. Map showing locations of three piezometers (red colour) drilled in Kłodzko underground water intake area

gional Water Management Board and the Kłodzko Waterworks Company (Fig. 1b). The chemical analyses of the underground water samples taken from 3 piezometers were carried out in the Chemical Laboratory of the Poltegor Institute in Wrocław $(13.01 .12,23.01 .12)$. In total, the values of 26 different quality and chemical parameters of the water were determined. The results were reported in [22].

In the third stage of the investigations, the data obtained from the three piezometers located in the water intake area were included in the database containing the water chemical analysis results, and the variations in the water quality parameters for 17 holes were analyzed.

Loose macro- and medium-clastic rocks were encountered in the lithologic profiles 
of the 22 wells in the Kłodzko underground water intake area. Pebbles, pebbles with sand, pebbles and small boulders with sand, gravel with pebbles, and rock debris (boulders with gravel and pebbles) predominated. The underground water table level ranged from $1.50 \mathrm{~m}$ to $4.75 \mathrm{~m}$ b.g.l. The drilled and stabilized underground water table was at the same depth below the ground level.

While drilling the three piezometers in the Kłodzko underground water intake area the following geological profile was found:

- to a depth of $4.5 \mathrm{~m}$ - pebbles with medium sand, grey in colour;

- at a depth of 4.5-10 m - gravel with coarse sand and medium sand, light grey in colour.

Exemplary base maps of the distributions of the topographical and hydrogeological parameters and of selected underground water quality parameters, calculated for 22 wells and 14 wells for the Kłodzko water intake area are shown in subsections 2.1. and 2.2.

Base maps of the distributions calculated for 14 wells and 3 piezometers and for 26 different quality parameters only related to the three new piezometers located in the water intake area are included in the report from the research carried out as part of the grant in the years 2011-2012 [22].

\subsection{DISTRIBUTIONS OF TOPOGRAPHICAL AND HYDROGEOLOGICAL PARAMETERS IN KŁODZKO UNDERGROUND WATER INTAKE AREA (22 WELLS)}

Base maps of the distributions of terrain elevations and values of hydrogeological parameters, determined for the wells located in the water intake area, are shown in Figs. $2-4$.

Base maps of distributions of topographical and hydrogeological parameters Terrain elevation 


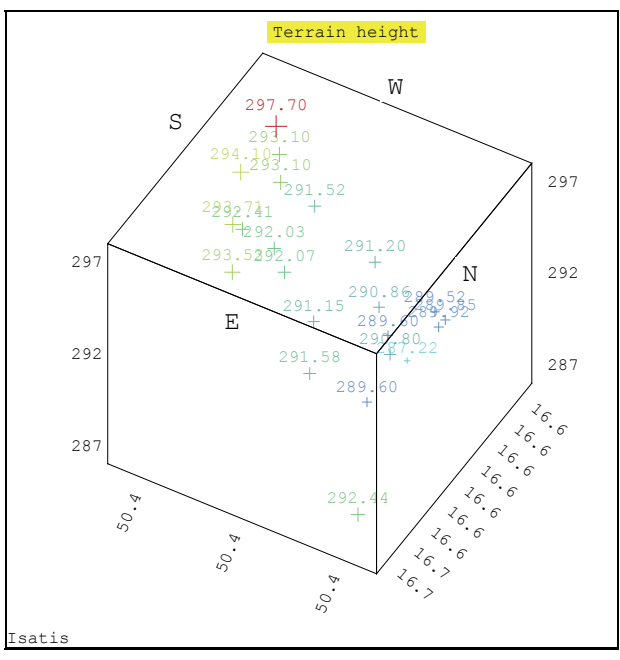

Fig. 2. Base map of terrain elevation [m a.s.1.] distribution in Kłodzko underground water intake area ( 22 wells)

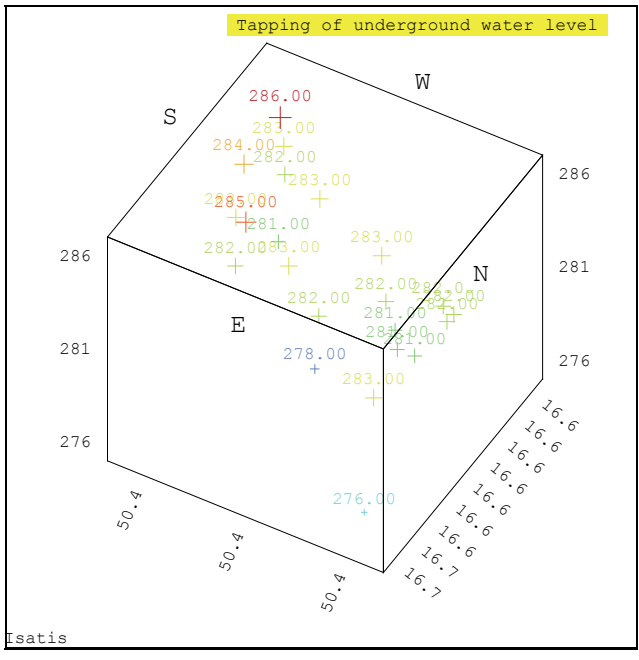

Fig. 3. Base map of distribution of water abstraction level $Z$ (dynamic water table) [m a.s.l.] in Kłodzko underground water intake area ( 22 wells)

Depth of occurrence of dynamic water table

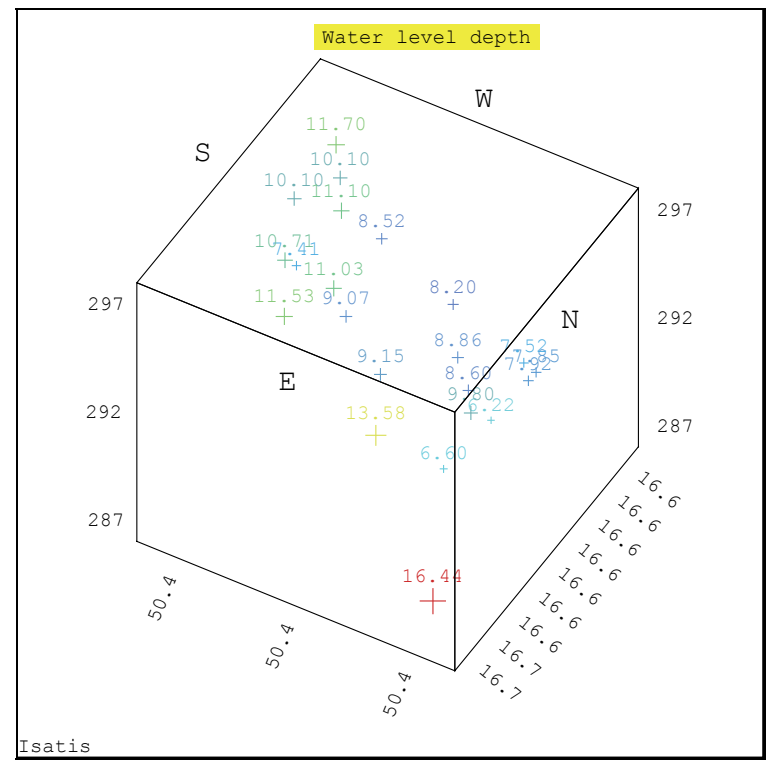

Fig. 4. Base map of distribution of dynamic water table depth occurrence [m b.g.l.] in Kłodzko underground water intake area (22 wells) 


\subsection{DISTRIBUTIONS OF \\ UNDERGROUND WATER QUALITY PARAMETERS \\ IN KŁODZKO WATER INTAKE AREA (14 WELLS)}

Figures 5 and 6 show exemplary base maps of the distributions of the values of two out of the eight underground water quality parameters, determined for the selected 14 wells located in the Kłodzko water intake area. The maps of Fe and Mn content distributions also show the location of the collector siphon well.

Base maps of the distributions of the underground water quality parameters: Fe content, Mn content and water oxidizing capacity for the Kłodzko water intake area, determined in the years 1977-2011 (for 12 measurement periods) can be found in [22].

Base maps of the distributions of $\mathrm{Fe}$ content and $\mathrm{Mn}$ content in the underground water and of the water reaction $\mathrm{pH}$, computed using the data coming from 14 wells and 3 piezometers installed in the water intake area in Kłodzko are presented in [22].

Base maps of distributions of underground water quality parameters

Fe content

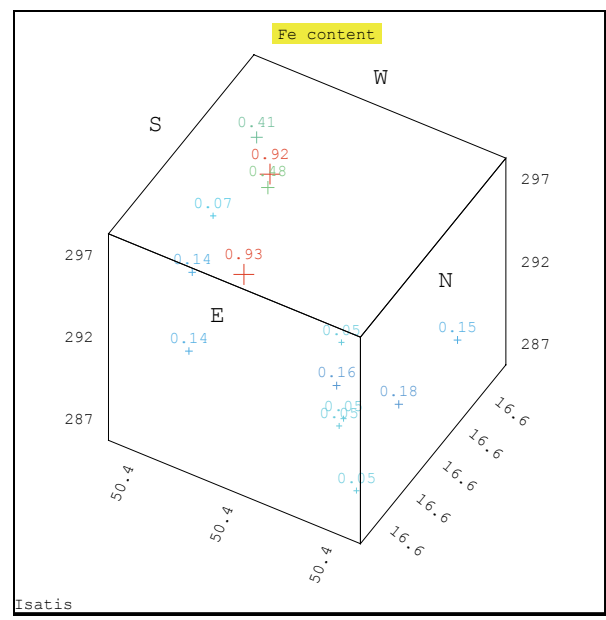

Fig. 5. Base map of Fe content $\left[\mathrm{gFe} / \mathrm{m}^{3}\right]$ distribution in Kłodzko underground water intake area (14 wells)
Mn content

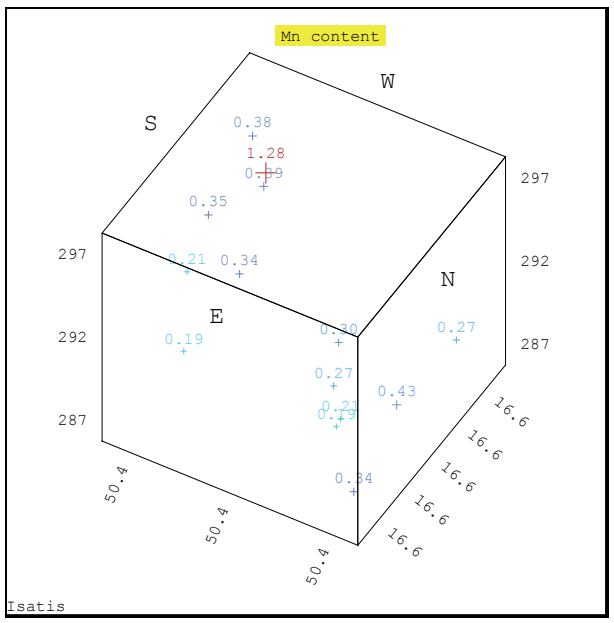

Fig. 6. Base map of Mn content $\left[\mathrm{gMn} / \mathrm{m}^{3}\right]$ distribution in Kłodzko underground water intake area (14 wells) 


\section{INVESTIGATIVE METHODOLOGY}

The geostatistical 3D analyses were carried out using such investigative methods as: the directional variogram function, ordinary block kriging and the power squared distances technique [1], [2], [4], [5], [12], [17], [18], [21], [24].

First, the statistical parameters were estimated and then the histograms of the distributions of the topographical, hydrogeological and quality parameters in the Kłodzko underground water intake area were analyzed. The preliminary analysis was based on the data acquired from 22 wells, from 14 selected wells (including the siphon well) and from 17 wells (14 wells +3 new piezometers). A structural (variographical) analysis [1], [2], [12], [21] of the parameters under consideration was carried out.

Then the underground water intake area was covered with a grid of elementary rectangular blocks. The following grid dimensions were adopted to estimate, using ordinary block kriging, the topographical parameter and the hydrogeological parameters on the basis of the data acquired from the 22 wells:

- the elementary area dimensions along axes $X, Y, Z: 0.0001 \mathrm{~m}, 0.00025 \mathrm{~m}$ and $0.1 \mathrm{~m}$;

- the number of grid nodes along axes $X, Y, Z: 88,48$ and 110 , respectively.

The above elementary grid dimensions were adopted for both the estimation of the topographical parameter and the hydrogeological parameters and the interpolation of their averages $Z^{*}$. The total number of elementary areas amounted to 464640 .

The same grid dimensions were adopted for the estimation of the underground water quality parameters over time on the basis of the data for the years 1977-2011. The total number of the estimated centres (nodes) of elementary blocks was 51840 .

For the estimation and interpolation of averages $Z^{*}$ of the quality parameters for the 14 wells and then for the 14 wells + the 3 piezometers, by means of ordinary block kriging and quick interpolation (the power squared distances method), the following elementary grid dimensions were adopted:

- the elementary area dimensions along axes $X, Y, Z: 0.0001 \mathrm{~m}, 0.00025 \mathrm{~m}$ and $0.1 \mathrm{~m}$;

- the number of grid nodes along axes $X, Y, Z: 58,46$ and 110, respectively.

The total numbers of elementary blocks, for whose centres means $Z^{*}$ of the water quality parameters were estimated, amounted to: 293480 (first variant of calculations for the 14 wells +3 piezometers) and 277200 (second variant of calculations for the 14 wells), respectively.

All the results yielded by ordinary kriging and the ones obtained by quick interpolation technique are reported in [22].

The results of the structural analysis and the ordinary block kriging estimation are to be shown in the subsequent papers presenting the geostatistical hydrogeochemical (3D) model for the Kłodzko underground water intake area. 


\section{ESTIMATION OF BASIC STATISTICS}

\subsection{ESTIMATION OF STATISTICAL, TOPOGRAPHICAL, HYDROGEOLOGICAL AND QUALITY PARAMETERS FOR KŁODZKO UNDERGROUND WATER INTAKE AREA} (22 WELLS)

Basic statistical parameters, such as minimal value $X_{\min }$, maximal value $X_{\max }$, the mean, standard deviation $S$ and variation coefficient $V$, were evaluated for the Kłodzko underground water intake area where the 22 wells are located. On this basis one can get some idea of: the topography of the terrain where the underground water intakes occur, water abstraction level $Z$ (taking into account the terrain elevation and the depth at which the dynamic water table occurs below the surface of the ground) and the quality of the water.

\subsubsection{ESTIMATION OF BASIC STATISTICS OF TOPOGRAPHICAL AND HYDROGEOLOGICAL PARAMETERS OF UNDERGROUND WATERS OVER YEARS 1977-1999}

The input for statistical computations was the archival data for the period 19771999. Tables 1 and 2 show the results of basic statistics evaluation for the topographical parameter (terrain elevation) and the hydrogeological parameters: underground water abstraction level $Z$ [m a.s.l.] (the dynamic water table) and the depth of an occurrence [m b.g.l.] of an underground water level in the Kłodzko underground water intake area.

The data on the 22 wells (Table 1) with their elevations ranging from 287.22 to $297.70 \mathrm{~m}$ a.s.l. (the average elevation $-291.68 \mathrm{~m}$ a.s.1.) were analyzed. Water abstraction level $Z$ (the dynamic water table) ranged from 276.00 to $286.00 \mathrm{~m}$ a.s.l., with the average water abstraction level amounting to $282.05 \mathrm{~m}$ a.s.l. (Table 2). The depth of occurrence of the dynamic water table ranged from 6.22 to $16.44 \mathrm{~m}$ b.g.l., with the average amounting to $9.64 \mathrm{~m}$ b.g.l.

Table 1

Basic statistics on terrain elevation in Kłodzko underground water intake area ( 22 wells)

\begin{tabular}{|c|c|c|c|c|c|c|}
\hline $\begin{array}{c}\text { Parameter } \\
\text { analyzed }\end{array}$ & $\begin{array}{c}\text { Sample } \\
\text { size } \\
n\end{array}$ & $\begin{array}{c}\text { Minimal } \\
\text { value } \\
X_{\min }\end{array}$ & $\begin{array}{c}\text { Maximal } \\
\text { value } \\
X_{\max }\end{array}$ & $\begin{array}{c}\text { Mean } \\
X\end{array}$ & $\begin{array}{c}\text { Standard } \\
\text { deviation } \\
S\end{array}$ & $\begin{array}{c}\text { Variation } \\
\text { coefficient } \\
V[\%]\end{array}$ \\
\hline $\begin{array}{c}\text { Terrain elevation } \\
\text { [m a.s.l.] }\end{array}$ & 22 & 287.22 & 297.70 & 291.68 & 2.10 & 1.00 \\
\hline
\end{tabular}

Table 2

Basic statistics on hydrogeological parameters in Kłodzko underground water intake area (22 wells)

\begin{tabular}{|c|c|c|c|c|c|c|}
\hline $\begin{array}{c}\text { Parameter } \\
\text { analyzed }\end{array}$ & $\begin{array}{c}\text { Sample } \\
\text { size }\end{array}$ & $\begin{array}{c}\text { Minimal } \\
\text { value }\end{array}$ & $\begin{array}{c}\text { Maximal } \\
\text { value }\end{array}$ & $\begin{array}{c}\text { Mean } \\
X\end{array}$ & $\begin{array}{c}\text { Standard } \\
\text { deviation }\end{array}$ & $\begin{array}{c}\text { Variation } \\
\text { coefficient }\end{array}$ \\
\hline
\end{tabular}




\begin{tabular}{|c|c|c|c|c|c|c|}
\hline & $n$ & $X_{\min }$ & $X_{\max }$ & & $S$ & $V[\%]$ \\
\hline $\begin{array}{c}\text { Water abstraction } \\
\text { level } Z \text { (dynamic } \\
\text { water table) } \\
\text { [m a.s.1.] }\end{array}$ & 22 & 276.00 & 286.00 & 282.05 & 2.03 & 1.00 \\
\hline $\begin{array}{c}\text { Depth of dynamic } \\
\text { water table } \\
\text { location [m b.g.1.] }\end{array}$ & 22 & 6.22 & 16.44 & 9.64 & 2.31 & 24.00 \\
\hline
\end{tabular}

4.1.2. ESTIMATION OF BASIC STATISTICS ON QUALITY PARAMETERS OF UNDERGROUND WATERS, BASED ON ARCHIVAL DATA FOR YEARS 1977-1999

The underground waters in the Quaternary water-bearing horizon in the Kłodzko Neisse river basin are mostly characterized by advantageous parameters [7], [8], [16], [19]. These are predominantly soft waters with slightly acid and neutral reaction $\mathrm{pH}$ (6-7.4) and low mineralization. The waters in this horizon were found to vary in their $\mathrm{Fe}$ and Mn compounds. In some of the wells the Fe content $\left(1.2-1.6 \mathrm{~g} / \mathrm{m}^{3}\right)$ was found to considerably exceed the permissible level for potable water $\left(\mathrm{Fe}<0.2 \mathrm{~g} / \mathrm{m}^{3}\right)$ while in the other wells the Fe content was within the obligatory limits $\left(0.12-0.3 \mathrm{~g} / \mathrm{m}^{3}\right)$. Also manganese occurred in considerable amounts $\left(0.12-0.3 \mathrm{~g} / \mathrm{m}^{3}\right)$, substantially exceeding the allowable level for drinking water $\left(\mathrm{Mn}<0.05 \mathrm{~g} / \mathrm{m}^{3}\right)$. The content of other components was found to be within the obligatory limits.

Tables 3-10 show the estimates of the basic statistics for the water quality parameters: Fe and Mn content values and oxidizing capacity, and the depths at which the dynamic underground water table occurs. The archival data on the chemical determinations of the above water parameters, performed for the particular wells (1-12) located in the Kłodzko water intake area, for the years 1977-1999 were analyzed.

The permissible values of the quality parameters under study are: $\mathrm{Fe}<0.200$ $\left[\mathrm{gFe} / \mathrm{m}^{3}\right]$, Mn content $<0.050\left[\mathrm{gMn} / \mathrm{m}^{3}\right]$ and oxidizing capacity $\left[5 \mathrm{gO}_{2} / \mathrm{m}^{3}\right]$.

Table 3

Means of quality parameters in Kłodzko underground water intake area, based on archival data for years 1977-1999

\begin{tabular}{|l|c|c|}
\hline \multicolumn{1}{|c|}{ Parameter analyzed } & Number of wells & Mean \\
& $n$ & $X$ \\
\hline Dynamic water table level (depth) [m b.g.1.] & 11 & 3.02 \\
\hline Fe content $\left[\mathrm{g} \mathrm{Fe} / \mathrm{m}^{3}\right]$ & 11 & 0.78 \\
\hline Mn content $\left[\mathrm{g} \mathrm{Mn} / \mathrm{m}^{3}\right]$ & 11 & 0.79 \\
\hline Oxidizing capacity $\left[\mathrm{g} \mathrm{O}_{2} / \mathrm{m}^{3}\right]$ & 11 & 3.11 \\
\hline
\end{tabular}

According to the estimates, the average values of $\mathrm{Fe}$ and $\mathrm{Mn}$ content for the whole pe- 
riod 1977-1999 (Table 3) significantly exceed the standard values adopted for these parameters, whereas the average oxidizing capacity does not exceed the standard value.

Tables 4-10 present the estimated means of the underground water quality parameters for the particular years, i.e., 1977, 1981, 1984, 1988, 1998 and 1999.

When examining the behaviour of the means of the parameters over the years 1977-1999 one can notice random (incidental) fluctuations in Fe content and a tendency to periodic changes in Mn content and also oxidizing capacity.

Basic statistics on quality parameters in Kłodzko underground water intake area, based on archival data for 1977

\begin{tabular}{|l|c|c|}
\hline \multicolumn{1}{|c|}{ Parameter analyzed } & $\begin{array}{c}\text { Sample size } \\
n\end{array}$ & $\begin{array}{c}\text { Mean } \\
\end{array}$ \\
\hline Fe content $\left[\mathrm{g} \mathrm{Fe} / \mathrm{m}^{3}\right]$ & 1 & 1.10 \\
\hline Mn content $\left[\mathrm{g} \mathrm{Mn} / \mathrm{m}^{3}\right]$ & 1 & 0.59 \\
\hline Oxidizing capacity $\left[\mathrm{g} \mathrm{O}_{2} / \mathrm{m}^{3}\right]$ & 1 & 2.72 \\
\hline
\end{tabular}

In 1977, the average values of $\mathrm{Fe}$ and Mn content significantly exceeded the standard values, whereas the average oxidizing capacity did not exceed the permissible value (Table 4).

Table 5

Basic statistics on water quality parameters for Kłodzko underground water intake area, based on archival data for 1981

\begin{tabular}{|l|c|c|}
\hline \multicolumn{1}{|c|}{ Parameter analyzed } & $\begin{array}{c}\text { Sample size } \\
n\end{array}$ & Mean \\
& 8 & 0.19 \\
\hline Fe content $\left[{\left.\mathrm{g} \mathrm{Fe} / \mathrm{m}^{3}\right]}^{\mathrm{M}}\right.$ Mn content $\left[\mathrm{g} \mathrm{Mn} / \mathrm{m}^{3}\right]$ & 8 & 0.27 \\
\hline Oxidizing capacity $\left[\mathrm{g} \mathrm{O}_{2} / \mathrm{m}^{3}\right]$ & 8 & 1.23 \\
\hline
\end{tabular}

In 1981 the average Mn content very significantly exceeded the standard value adopted for this parameter (Table 5), whereas the proved Fe content was slightly lower than the standard value and the average oxidizing capacity was much lower than the permissible value.

Basic statistics on water quality parameters in Kłodzko underground water intake area, based on archival data for 1984 


\begin{tabular}{|l|c|c|}
\hline \multicolumn{1}{|c|}{ Parameter analyzed } & Sample size & Mean \\
& $n$ & $X$ \\
\hline Fe content $\left[\mathrm{g} \mathrm{Fe} / \mathrm{m}^{3}\right]$ & 8 & 0.04 \\
\hline Mn content $\left[\mathrm{g} \mathrm{Mn} / \mathrm{m}^{3}\right]$ & 8 & 0.71 \\
\hline Oxidizing capacity $\left[\mathrm{g} \mathrm{O}_{2} / \mathrm{m}^{3}\right]$ & 8 & 1.87 \\
\hline
\end{tabular}

In 1984, out of the parameters analyzed only the mean Mn content exceeded the permissible value for this element (Table 6).

Table 7

Basic statistics on water quality parameters in Kłodzko underground water intake area, based on archival data for 1988

\begin{tabular}{|l|c|c|}
\hline \multicolumn{1}{|c|}{ Parameter analyzed } & Sample size & Mean \\
& $n$ & $X$ \\
\hline Fe content $\left[\mathrm{g} \mathrm{Fe} / \mathrm{m}^{3}\right]$ & 12 & 0.12 \\
\hline Mn content $\left[\mathrm{g} \mathrm{Mn} / \mathrm{m}^{3}\right]$ & 12 & 0.28 \\
\hline Oxidizing capacity $\left[\mathrm{g} \mathrm{O}_{2} / \mathrm{m}^{3}\right]$ & 12 & 2.37 \\
\hline
\end{tabular}

The situation is similar for 1988, i.e., only the mean Mn content exceeded the permissible value adopted for this element (Table 7).

\section{Table 8}

Basic statistics of water quality parameters in Kłodzko underground water intake area based on archival data for September 1998

\begin{tabular}{|l|c|c|}
\hline \multicolumn{1}{|c|}{ Parameter analyzed } & $\begin{array}{c}\text { Sample size } \\
n\end{array}$ & $\begin{array}{c}\text { Mean } \\
X\end{array}$ \\
\hline Fe content $\left[\mathrm{g} \mathrm{Fe} / \mathrm{m}^{3}\right]$ & 1 & 0.07 \\
\hline Mn content $\left[\mathrm{g} \mathrm{Mn} / \mathrm{m}^{3}\right]$ & 1 & 0.56 \\
\hline Oxidizing capacity $\left[\mathrm{g} \mathrm{O}_{2} / \mathrm{m}^{3}\right]$ & 1 & 2.00 \\
\hline
\end{tabular}

Table 9

Basic statistics on water quality parameters in Kłodzko underground water intake area, based on archival data for November 1998

\begin{tabular}{|l|c|c|}
\hline \multicolumn{1}{|c|}{ Parameter analyzed } & Sample size & Mean \\
& $n$ & $X$ \\
\hline Fe content $\left[\mathrm{g} \mathrm{Fe}^{3} \mathrm{~m}^{3}\right]$ & 1 & 0.03 \\
\hline Mn content $\left[\mathrm{g} \mathrm{Mn} / \mathrm{m}^{3}\right]$ & 1 & 0.72 \\
\hline Oxidizing capacity $\left[\mathrm{g} \mathrm{O}_{2} / \mathrm{m}^{3}\right]$ & 1 & 2.39 \\
\hline
\end{tabular}


In September and November 1998, only Mn content exceeded the adopted permissible value for this element (Tables 8-9).

Table 10

Basic statistics on water quality parameters in Kłodzko underground water intake area, based on archival data for January 1999

\begin{tabular}{|l|c|c|}
\hline \multicolumn{1}{|c|}{ Parameter analyzed } & $\begin{array}{c}\text { Sample size } \\
n\end{array}$ & Mean \\
& 1 & $X$ \\
\hline $\mathrm{Fe}$ content $\left[\mathrm{g} \mathrm{Fe} / \mathrm{m}^{3}\right]$ & 1 & 0.44 \\
\hline Mn content $\left[\mathrm{g} \mathrm{Mn} / \mathrm{m}^{3}\right]$ & 1 & 0.42 \\
\hline Oxidizing capacity $\left[\mathrm{g} \mathrm{O}_{2} / \mathrm{m}^{3}\right]$ & 1.55 \\
\hline
\end{tabular}

In 1999 (January), the mean values of $\mathrm{Fe}$ and Mn content exceed the adopted standard values for the elements (Table 10).

To sum up, the mean Mn content in the underground water exceeded the adopted standard value in all the cases (1977-1999) while the Fe content did so in two cases (1977, 1999): in one of the cases being very close to the standard value (1981). In the years 1977-1999, the mean oxidizing capacity did not exceed the permissible value, reaching sometimes higher and sometimes lower values.

\subsection{ESTIMATION OF BASIC STATISTICS \\ ON UNDERGROUND WATER QUALITY PARAMETERS OVER YEARS 1977-1999}

The estimates of the coefficients of variation $V$ in the underground water quality parameters for the 22 wells located in the water intake area, based on the archival data for the years 1977-1999, indicate extremely high variation in Fe content, very high variation in $\mathrm{Mn}$ content and high variation in oxidizing capacity (Table 11). The maximal values of Fe content and Mn content exceed the permissible standard values and in the case of Mn content this also applies to the mean value. In the case of the oxidizing capacity, the calculated statistics do not exceed the permissible value for this parameter.

Table 11

Basic statistics on water quality parameters in Kłodzko underground water intake area (22 wells)

\begin{tabular}{|c|c|c|c|c|c|c|}
\hline $\begin{array}{c}\text { Parameter } \\
\text { analyzed }\end{array}$ & $\begin{array}{c}\text { Sample } \\
\text { size } \\
n\end{array}$ & $\begin{array}{c}\text { Minimal } \\
\text { value } \\
X_{\min }\end{array}$ & $\begin{array}{c}\text { Maximal } \\
\text { value } \\
X_{\max }\end{array}$ & $\begin{array}{c}\text { Mean } \\
X\end{array}$ & $\begin{array}{c}\text { Standard } \\
\text { deviation } \\
S\end{array}$ & $\begin{array}{c}\text { Variation } \\
\text { coefficient } \\
V[\%]\end{array}$ \\
\hline Fe content $\left[\mathrm{g} \mathrm{Fe}^{3} \mathrm{~m}^{3}\right]$ & 22 & 0.0000 & 1.1000 & 0.1709 & 0.2301 & 134.61 \\
\hline
\end{tabular}




\begin{tabular}{|l|c|c|c|c|c|c|}
\hline Mn content $\left[\mathrm{g} \mathrm{Mn} / \mathrm{m}^{3}\right]$ & 22 & 0.0600 & 1.8400 & 0.5023 & 0.5237 & 104.27 \\
\hline Oxidizing capacity $\left[\mathrm{g} \mathrm{O}_{2} / \mathrm{m}^{3}\right]$ & 22 & 0.4800 & 3.1200 & 1.6336 & 0.7458 & 45.65 \\
\hline
\end{tabular}

\subsection{ESTIMATION OF STATISTICAL PARAMETERS OF WATER QUALITY FOR KŁODZKO UNDERGROUND WATER INTAKE AREA (14 WELLS)}

Basic statistics, such as minimal values $X_{\min }$, maximal values $X_{\max }$, mean values, standard deviation $(S)$ values and variation coefficients $V$ of the water quality parameters, for the Kłodzko underground water intake area were evaluated on the basis of the results of the chemical analyses (made on 15.11.2011) of the water coming from 14 wells. The subject of the estimation included eight parameters: $\mathrm{Fe}, \mathrm{Mn}$, ammonium ion $\mathrm{NH}_{4}^{+}$, nitrite anion $\mathrm{NO}_{3}^{-}$and phosphate anion $\mathrm{PO}_{4}^{-3}$ content values, moreover total organic carbon (TOC) $\mathrm{C}$ content, $\mathrm{pH}$ potential, temperature ${ }^{\circ} \mathrm{C}$.

\subsubsection{ESTIMATION OF BASIC STATISTICS OF UNDERGROUND WATER QUALITY PARAMETERS, BASED ON DATA ACQUIRED IN 2011 (14 WELLS)}

The estimates of the basic statistics on the underground water quality parameters for the 14 wells (15.11.2011) are shown in Table 12. When examining the values of coefficient $V$ of the particular parameters one finds that Fe content and $\mathrm{NO}_{3}^{-}$anion content vary greatly. One should also notice the high variation in $\mathrm{Mn}$ content and ammonium ion $\mathrm{NH}_{4}^{+}$content for which identical values of variation coefficient $V$ were obtained. Temperature ${ }^{\circ} \mathrm{C}$ and $\mathrm{pH}$ redox potential show extremely small variation.

The estimates of the maximal, average and minimal $\mathrm{Fe}$ and $\mathrm{Mn}$ content show that the standard values for these elements are significantly exceeded (Table 12). The maximal ammonium ion $\mathrm{NH}_{4}^{+}$content in the water is close to the standard value. In the case of the other parameters, the statistics indicate no exceedance of the standard values.

Table 12

Basic statistics of water quality parameters in Kłodzko underground water intake area for 14 wells (15.11.2011)

\begin{tabular}{|l|c|c|c|c|c|c|}
\hline $\begin{array}{c}\text { Variable } \\
\text { analyzed }\end{array}$ & $\begin{array}{c}\text { Sample } \\
\text { size } \\
n\end{array}$ & $\begin{array}{c}\text { Minimal } \\
\text { value } \\
X_{\min }\end{array}$ & $\begin{array}{c}\text { Maximal } \\
\text { value } \\
X_{\max }\end{array}$ & $\begin{array}{c}\text { Mean } \\
X\end{array}$ & $\begin{array}{c}\text { Standard } \\
\text { deviation } \\
S\end{array}$ & $\begin{array}{c}\text { Variation } \\
\text { coefficient } \\
V[\%]\end{array}$ \\
\hline $\mathrm{pH}$ & 14 & 6.04 & 6.87 & 6.50 & 0.25 & 4.00 \\
\hline Temperature ${ }^{\circ} \mathrm{C}$ & 14 & 7.30 & 9.80 & 7.97 & 0.63 & 8.00 \\
\hline Fe content $\left[\mathrm{g} \mathrm{Fe} / \mathrm{m}^{3}\right]$ & 14 & 0.05 & 0.93 & 0.27 & 0.30 & 110.00 \\
\hline
\end{tabular}




\begin{tabular}{|c|c|c|c|c|c|c|}
\hline Mn content $\left[\mathrm{g} \mathrm{Mn} / \mathrm{m}^{3}\right]$ & 14 & 0.19 & 1.28 & 0.37 & 0.26 & 72.00 \\
\hline $\begin{array}{l}\text { Ammonium ion content } \\
{\left[\mathrm{g} \mathrm{NH}_{4}^{+} / \mathrm{m}^{3}\right]}\end{array}$ & 14 & 0.08 & 0.47 & 0.15 & 0.11 & 72.00 \\
\hline $\begin{array}{l}\text { Nitrite anion } \\
\mathrm{NO}_{3}^{-} \text {content }\left[\mathrm{g} \mathrm{NO}_{3}^{-} / \mathrm{m}^{3}\right]\end{array}$ & 14 & 0.13 & 3.48 & 0.88 & 0.82 & 94.00 \\
\hline $\begin{array}{l}\text { Phosphate anion } \mathrm{PO}_{4}^{-3} \text { content } \\
{\left[\mathrm{g} \mathrm{PO}_{4}^{-3} / \mathrm{m}^{3}\right]}\end{array}$ & 14 & 0.06 & 0.24 & 0.11 & 0.05 & 44.00 \\
\hline $\begin{array}{l}\text { Total organic carbon (TOC) } \\
\text { C content }\left[\mathrm{g} \mathrm{C}^{3} \mathrm{~m}^{3}\right]\end{array}$ & 14 & 0.71 & 1.54 & 1.09 & 0.18 & 17.00 \\
\hline
\end{tabular}

The permissible values of water quality parameters:

$-\mathrm{Fe}$ content $<0.200\left[\mathrm{~g} \mathrm{Fe} / \mathrm{m}^{3}\right]$,

- Mn content $<0.050\left[\mathrm{~g} \mathrm{Mn}^{3} \mathrm{~m}^{3}\right]$,

- ammonium ion $\mathrm{NH}_{4}^{+}$content $<0.500\left[\mathrm{~g} \mathrm{NH}_{4}^{+} / \mathrm{m}^{3}\right.$ ],

- nitrite anion $\mathrm{NO}_{3}^{-}$content $\left[50 \mathrm{~g} \mathrm{NO}_{3} / \mathrm{m}^{3}\right]$,

- phosphate anion $\mathrm{PO}_{4}^{-3}$ content in off-specification potable water,

- total organic carbon (TOC) content $\mathrm{C}\left[5 \mathrm{~g} \mathrm{C}^{-\mathrm{m}^{3}}\right]$,

- oxidizing capacity $-\left[5 \mathrm{~g} \mathrm{O}_{2} / \mathrm{m}^{3}\right]$.

Table 13 shows the mean values of the particular water quality parameters, including the data for the collector siphon well and excluding these data for a similar sample size. The comparison shows that the means of the parameters analyzed are identical or the differences between them are minimal and so statistically insignificant.

Table 13

Mean values of particular water quality parameters in Kłodzko underground water intake area for 13 and 14 wells (15.11.2011).

\begin{tabular}{|c|c|c|c|c|}
\hline $\begin{array}{c}\text { Variable } \\
\text { analyzed }\end{array}$ & $\begin{array}{c}\text { Number } \\
\text { of wells } \\
n\end{array}$ & $\begin{array}{c}\text { Mean } X \\
\text { (with collector } \\
\text { siphon well) }\end{array}$ & $\begin{array}{c}\text { Number } \\
\text { of wells } \\
n\end{array}$ & $\begin{array}{c}\text { Mean } X \\
\text { (without collector } \\
\text { siphon well) }\end{array}$ \\
\hline Redox potential $[\mathrm{pH}]$ & 14 & 6.50 & 13 & 6.49 \\
\hline Temperature $\left[{ }^{\circ} \mathrm{C}\right]$ & 14 & 7.97 & 13 & 8.00 \\
\hline $\mathrm{Fe}$ content $\left[\mathrm{g} \mathrm{Fe} / \mathrm{m}^{3}\right]$ & 14 & 0.27 & 13 & 0.28 \\
\hline Mn content $\left[\mathrm{g} \mathrm{Mn} / \mathrm{m}^{3}\right]$ & 14 & 0.37 & 13 & 0.38 \\
\hline $\begin{array}{l}\text { Ammonium ion } \mathrm{NH}_{4}^{+} \text {content } \\
{\left[\mathrm{g} \mathrm{NH}_{4}^{+} / \mathrm{m}^{3}\right]}\end{array}$ & 14 & 0.15 & 13 & 0.15 \\
\hline $\begin{array}{l}\text { Nitrite anion } \mathrm{NO}_{3}^{-} \text {content } \\
{\left[\mathrm{g} \mathrm{NO}_{3}^{-} / \mathrm{m}^{3}\right]}\end{array}$ & 14 & 0.88 & 13 & 0.86 \\
\hline $\begin{array}{l}\text { Phosphate anion } \mathrm{PO}_{4}^{-3} \text { content } \\
{\left[\mathrm{g} \mathrm{PO}_{4}^{-3} / \mathrm{m}^{3}\right]}\end{array}$ & 14 & 0.11 & 13 & 0.10 \\
\hline
\end{tabular}




\begin{tabular}{|l|l|l|l|l|}
\hline $\begin{array}{l}\text { Total organic carbon (TOC) } \\
\mathrm{C} \text { content }\left[\mathrm{g} \mathrm{C} / \mathrm{m}^{3}\right]\end{array}$ & 14 & 1.09 & 13 & 1.07 \\
\hline
\end{tabular}

Table 14 shows the outlier values for the chemical determinations of the underground water quality parameters for 14 wells, stored in the database. No outlier values were found for $\mathrm{Fe}$ content and $\mathrm{pH}$.

Outlier values for water quality parameters in Kłodzko underground water intake area (14 wells)

\begin{tabular}{|l|c|c|}
\hline \multicolumn{1}{|c|}{ Variable analyzed } & $\begin{array}{c}\text { Sample size } \\
n\end{array}$ & Outlier value \\
\hline Temperature $\left[{ }^{\circ} \mathrm{C}\right]$ & 14 & 9.80 \\
\hline Mn content $\left[\mathrm{g} \mathrm{Mn} / \mathrm{m}^{3}\right]$ & 14 & 1.28 \\
\hline Ammonium ion $\mathrm{NH}_{4}^{+}$content $\left[\mathrm{g} \mathrm{NH}_{4}^{+} / \mathrm{m}^{3}\right]$ & 14 & 0.28 \\
& 14 & 0.47 \\
\hline Nitrite anion $\mathrm{NO}_{3}^{-}$content $\left[\mathrm{g} \mathrm{NO}_{3}^{-} / \mathrm{m}^{3}\right]$ & 14 & 3.48 \\
\hline Phosphate anion $\mathrm{PO}_{4}$ content $\left[\mathrm{g} \mathrm{PO}_{4}^{-3} / \mathrm{m}^{3}\right]$ & 14 & 0.24 \\
\hline Total organic carbon $(\mathrm{TOC})$ content $\left[\mathrm{g} \mathrm{C} / \mathrm{m}^{3}\right]$ & & 1.54 \\
\hline
\end{tabular}

\subsection{ESTIMATION OF STATISTICS ON WATER QUALITY PARAMETERS IN KŁODZKO UNDERGROUND WATER INTAKE AREA (14 WELLS + 3 PIEZOMETERS)}

The estimates of the basic statistics on the underground water quality parameters for the Kłodzko water intake area, taking into account the data for the 14 wells and the data for the three new piezometers (obtained in January 2012), indicate extremely high variation in Fe content, high or average variation in Mn content and very low variation in water $\mathrm{pH}$ (Table 15).

Undoubtedly the results of the chemical analyses of Fe content and Mn content in the water carried out for the three piezometers (Table 16) influence the estimates of the statistical parameters for the total of 17 holes (Table 15). Maximal value $X_{\max }$ and mean values of Fe content were considerably exceeded and in the case of Mn content, besides the above statistics, even minimal value $X_{\min }$ was exceeded (Table 16).

Basic statistics on water quality parameters in Kłodzko underground water intake area in period 2011-2012 (14 wells +3 piezometers) 


\begin{tabular}{|l|c|c|c|c|c|c|}
\hline $\begin{array}{c}\text { Variable } \\
\text { analyzed }\end{array}$ & $\begin{array}{c}\text { Sample } \\
\text { size } \\
n\end{array}$ & $\begin{array}{c}\text { Minimal } \\
\text { value } \\
X_{\min }\end{array}$ & $\begin{array}{c}\text { Maximal } \\
\text { value } \\
X_{\max }\end{array}$ & $\begin{array}{c}\text { Mean } \\
X\end{array}$ & $\begin{array}{c}\text { Standard } \\
\text { deviation } \\
S\end{array}$ & $\begin{array}{c}\text { Variation } \\
\text { coefficient } \\
V[\%]\end{array}$ \\
\hline Fe content $\left[\mathrm{g} \mathrm{Fe} / \mathrm{m}^{3}\right]$ & 17 & 0.0500 & 6.1200 & 1.1276 & 1.9079 & 169.19 \\
\hline Mn content $\left[\mathrm{g} \mathrm{Mn} / \mathrm{m}^{3}\right]$ & 17 & 0.1900 & 1.2800 & 0.3635 & 0.2436 & 67.00 \\
\hline $\mathrm{pH}$ reaction & 17 & 6.0400 & 7.4100 & 6.6476 & 0.3917 & 5.89 \\
\hline
\end{tabular}

\subsection{ESTIMATION OF STATISTICS ON WATER QUALITY PARAMETERS FOR KŁODZKO UNDERGROUND WATER INTAKE AREA (3 PIEZOMETERS)}

The permissible values of $\mathrm{Fe}$ and $\mathrm{Mn}$ content were found to be considerably exceeded in the three piezometers installed in the Kłodzko water intake area. Minimal content $X_{\min }$, maximal content $X_{\max }$ and the mean content of the elements in the underground water were found to be very high (Table 16).

The values of $\mathrm{Mg}$, heavy metals $(\mathrm{Cd}, \mathrm{Cr}, \mathrm{Cu}, \mathrm{Pb})$, chlorides $\mathrm{Cl}$, fluorides $\mathrm{F}$ and ammonium $\mathrm{NH}_{4}$, sulphate anion $\mathrm{SO}_{4}^{-2}$ content in the water coming from the three piezometers are considerably lower than the adopted permissible values [22]. This also applies to electrical conductivity, the potassium permanganate index and total water hardness.

Variation coefficients $V$ calculated on the basis of the data acquired from the three piezometers indicate low variation in Fe content and average variation in $\mathrm{Mn}$ content (Table 16). Coefficients $V$ of: $\mathrm{Ca}, \mathrm{Mg}$. Pb, sulphates, $\mathrm{Zn}$, hydrogencarbonates, chlorides and fluorides content and the electrical conductivity values indicate low variation in the parameters [22]. Coefficients $V$ of potassium content $\mathrm{K}$ and tetraoxomanganate (oxidation) index indicate even lower variation (but already close to average) in the parameters. The other parameters analyzed: various kinds of hardness (total, carbonate, non-carbonate hardness) and dissolved substances are characterized by low or minimal values of coefficient $V$ (total $\mathrm{Cr}$ content, $\mathrm{pH}$ reaction). The changes in $\mathrm{Cd}$ and $\mathrm{Cr}$ contents have an average character.

Table 16

Basic statistics on water quality parameters in Kłodzko underground water intake area for 2012 (3 piezometers)

\begin{tabular}{|l|c|c|c|c|c|c|}
\hline $\begin{array}{c}\text { Variable } \\
\text { analyzed }\end{array}$ & $\begin{array}{c}\text { Sample } \\
\text { size } \\
n\end{array}$ & $\begin{array}{c}\text { Minimal } \\
\text { value } \\
X_{\min }\end{array}$ & $\begin{array}{c}\text { Maximal } \\
\text { value } \\
X_{\max }\end{array}$ & $\begin{array}{c}\text { Mean } \\
X\end{array}$ & $\begin{array}{c}\text { Standard } \\
\text { deviation } \\
S\end{array}$ & $\begin{array}{c}\text { Variation } \\
\text { coefficient } \\
V[\%]\end{array}$ \\
\hline Fe content $\left[\mathrm{g} \mathrm{Fe} / \mathrm{m}^{3}\right]$ & 3 & 3.9900 & 6.1200 & 5.1300 & 0.8760 & 17.08 \\
\hline Mn content $\left[\mathrm{g} \mathrm{Mn} / \mathrm{m}^{3}\right]$ & 3 & 0.2100 & 0.4600 & 0.3433 & 0.1027 & 29.92 \\
\hline $\mathrm{pH}$ reaction & 3 & 7.1700 & 7.4100 & 7.3233 & 0.1087 & 1.48 \\
\hline
\end{tabular}

The permissible values of quality parameters in potable water: 
- Fe content $<0.200\left[\mathrm{~g} \mathrm{Fe} / \mathrm{m}^{3}\right]$,

- Mn content $<0.050\left[\mathrm{~g} \mathrm{Mn} / \mathrm{m}^{3}\right]$.

\section{ANALYSIS OF DISTRIBUTION HISTOGRAMS}

From among the histograms of the topographical, the hydrogeological and quality parameters of the underground water in the Kłodzko water intake area [22] which were investigated, only the histograms of the quality parameters for 14 wells are presented here (Figs. 7-14).

\subsection{DISTRIBUTION HISTOGRAMS OF QUALITY PARAMETERS OF UNDERGROUND WATER, BASED ON DATA FOR 2011 (14 WELLS)}

The distribution histograms of some of the quality parameters analyzed are strongly asymmetrical single-side histograms. This type of distribution was found for Fe content (Fig. 7), ammonium ion $\mathrm{NH}_{4}^{+}$content (Fig. 9) and nitrite anion $\mathrm{NO}_{3}^{-}$ content (Fig. 10). The distributions have a clearly multimodal character, as in the case of Mn content (Fig. 8), phosphate anion $\mathrm{PO}_{4}^{-3}$ content (Fig. 12), pH redox potential (Fig. 13), temperature ${ }^{\circ} \mathrm{C}$ (Fig. 14) and total organic carbon (TOC) C content (Fig. 11).

Fe content

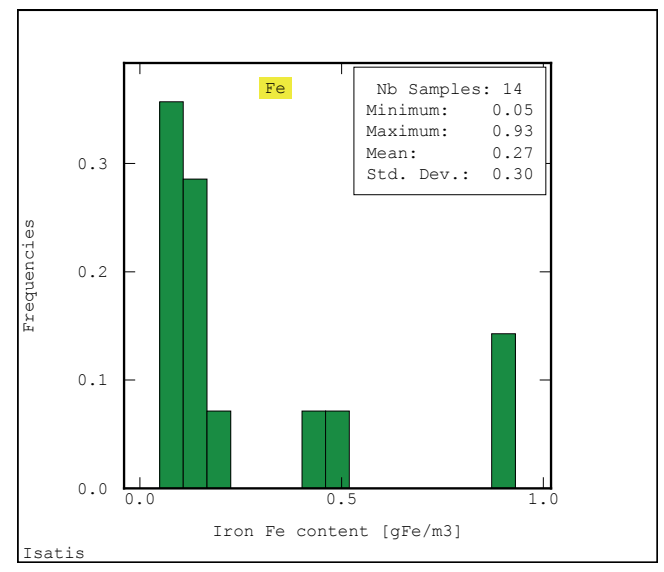

Fig. 7. Distribution histogram of Fe content $\left[\mathrm{g} \mathrm{Fe} / \mathrm{m}^{3}\right]$ in underground water in Kłodzko water intake area
Mn content

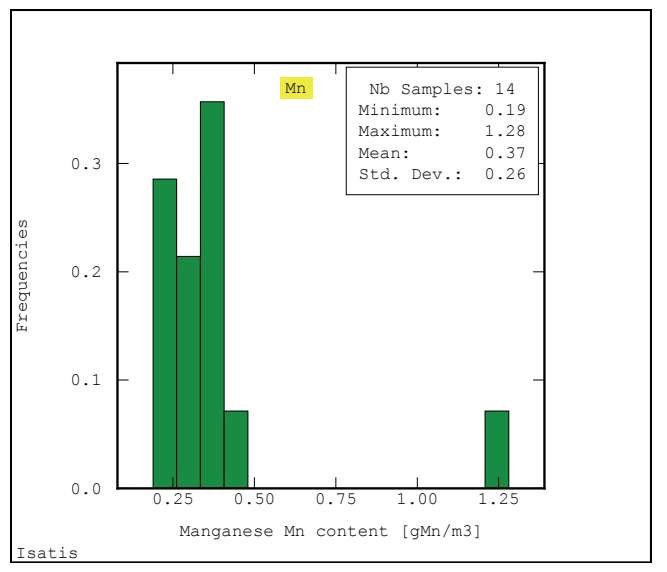

Fig. 8. Distribution histogram of Mn content $\left[\mathrm{g} \mathrm{Mn} / \mathrm{m}^{3}\right]$ in underground water in Kłodzko water intake area 
Ammonium $\mathrm{NH}_{4}^{+}$content

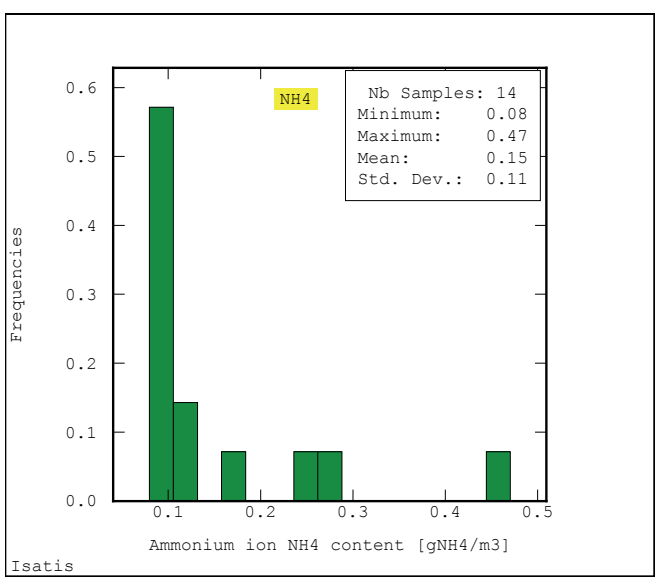

Fig. 9. Distribution histogram of ammonium ion content $\left[\mathrm{g} \mathrm{NH}_{4}^{+} / \mathrm{m}^{3}\right]$ in underground water in Kłodzko water intake area

Total organic carbon (TOC) content C

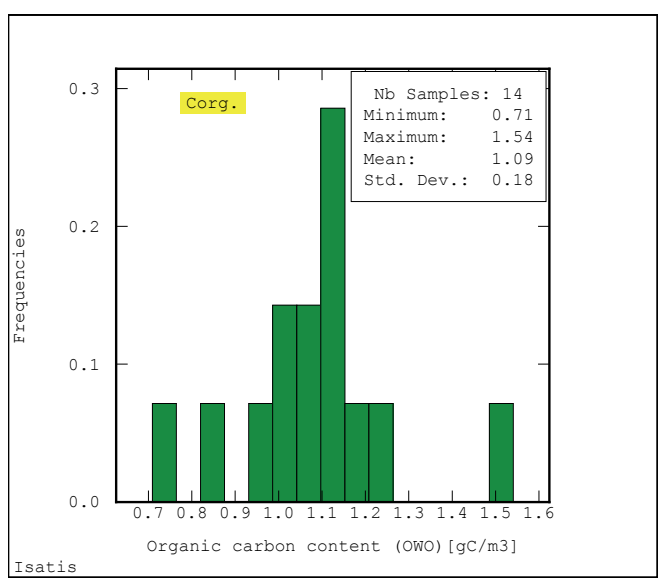

Fig. 11. Distribution histogram of total organic carbon (TOC) content $\mathrm{C}$

$\left[\mathrm{g} \mathrm{C} / \mathrm{m}^{3}\right]$ in underground water in Kłodzko water intake area
Nitrite anion $\mathrm{NO}_{3}^{-}$content

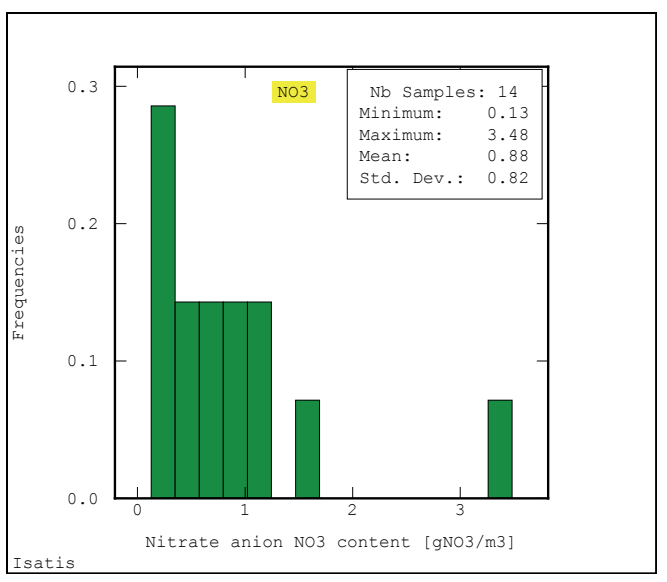

Fig. 10. Distribution histogram of nitrite anion $\left[\mathrm{g} \mathrm{NO}_{3}^{-} / \mathrm{m}^{3}\right]$ in underground water in Kłodzko water intake area.intake area
Phosphate anion $\mathrm{PO}_{4}^{-3}$ content

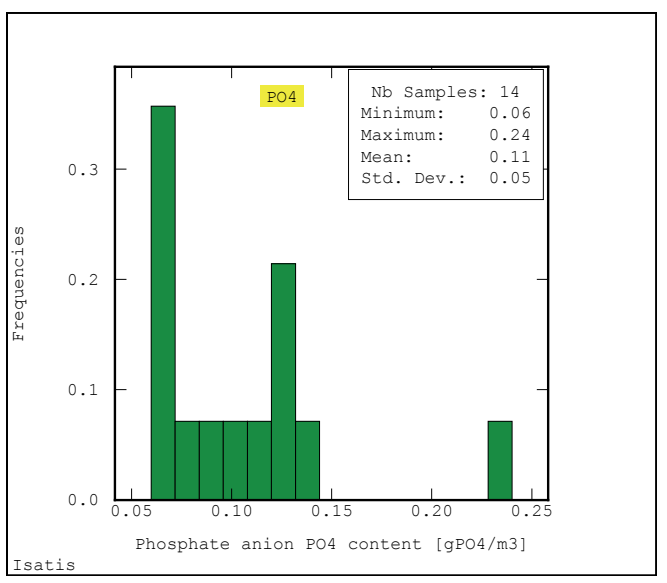

Fig. 12. Distribution histogram of phosphate anion $\left[\mathrm{PO}_{4}^{-3}\right]$ content in underground water in Kłodzko water intake area 
$\mathrm{pH}$ redox potential

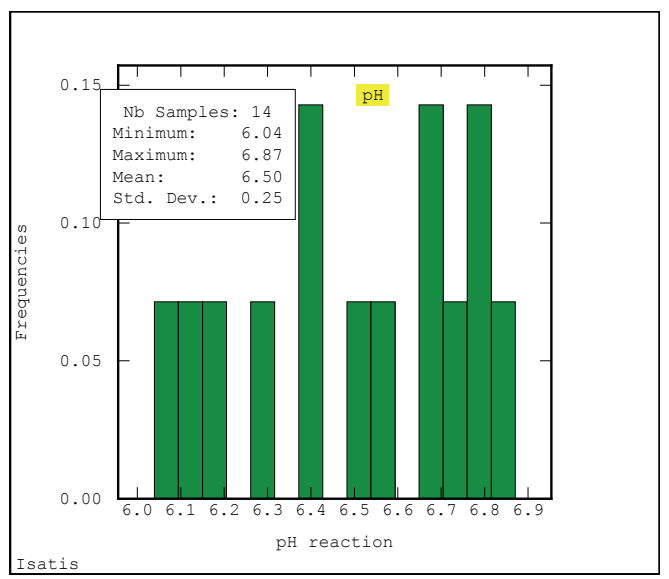

Fig. 13. Distribution histogram of $\mathrm{pH}$ redox potential of underground water in Kłodzko water intake area
Temperature ${ }^{\circ} \mathrm{C}$

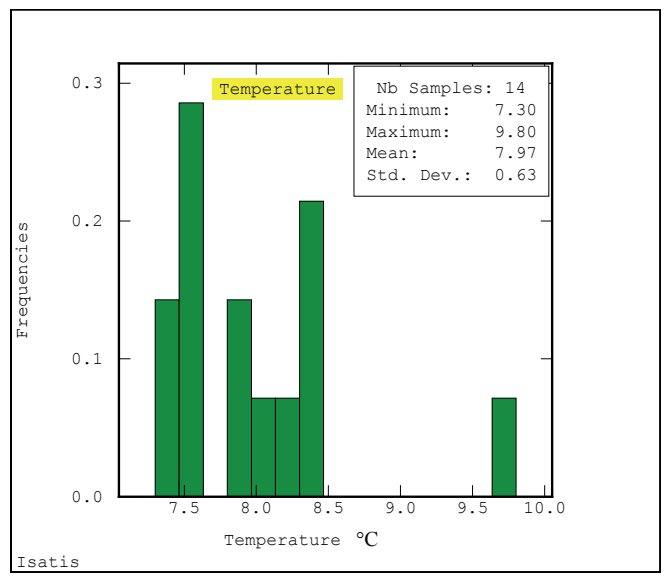

Fig. 14. Distribution histogram of temperature ${ }^{\circ} \mathrm{C}$ [degrees] of underground water in Kłodzko water intake area

The distribution histograms of most of the parameters analyzed are characterized by stronger or weaker positive skewness, except for the histogram of $\mathrm{pH}$ potential which shows slight negative skewness (Table 17). The highest values of skewness coefficient $g_{1}$ were obtained for $\mathrm{Mn}$ content and nitrite anion $\mathrm{NO}_{3}^{-}$content, whereas the lowest values of $g_{1}$ were obtained for organic carbon content. The distribution of $\mathrm{Mn}$ content is characterized by the most slender histogram and at the same time by the highest value of kurtosis coefficient $g_{2}$.

Table 17

Skewness $g_{1}$ and kurtosis $g_{2}$ of distribution histograms of water quality parameters in Kłodzko underground water intake area (14 wells)

\begin{tabular}{|c|c|c|}
\hline Parameter analyzed & Skewness $g_{1}$ & Kurtosis $g_{2}$ \\
\hline $\mathrm{pH}$ & -0.33 & 1.86 \\
\hline Temperature $\left[{ }^{\circ} \mathrm{C}\right]$ & 1.55 & 5.41 \\
\hline Fe content $\left[\mathrm{g} \mathrm{Fe} / \mathrm{m}^{3}\right]$ & 1.42 & 3.58 \\
\hline Mn content $\left[\mathrm{g} \mathrm{Mn} / \mathrm{m}^{3}\right]$ & 2.87 & 10.24 \\
\hline Ammonium ion $\mathrm{NH}_{4}^{+}$content $\left[\mathrm{g} \mathrm{NH}_{4}^{+} / \mathrm{m}^{3}\right]$ & 1.94 & 5.84 \\
\hline Nitrite anion $\mathrm{NO}_{3}$ content $\left[\mathrm{g} \mathrm{NO}_{3}^{-} / \mathrm{m}^{3}\right]$ & 2.13 & 7.37 \\
\hline Phosphate anion $\mathrm{PO}_{4}^{-3}$ content $\left[\mathrm{g} \mathrm{P} \mathrm{O}_{4}^{-3} / \mathrm{m}^{3}\right]$ & 1.56 & 5.34 \\
\hline Total organic carbon (TOC) content $\mathrm{C}\left[\mathrm{gC} / \mathrm{m}^{3}\right]$ & 0.39 & 4.33 \\
\hline
\end{tabular}




\subsection{DISTRIBUTION HISTOGRAMS OF UNDERGROUND WATER QUALITY PARAMETERS, BASED ON DATA FOR PERIOD 2011-2012 (14 WELLS + 3 PIEZOMETERS)}

Distribution histograms of three underground water quality parameters: Fe content, $\mathrm{Mn}$ content and $\mathrm{pH}$ potential, calculated for the data acquired in the period 15.11.201123.01.2012 for 14 wells and 3 piezometers (Figs. 15-17), are presented below.

Fe content

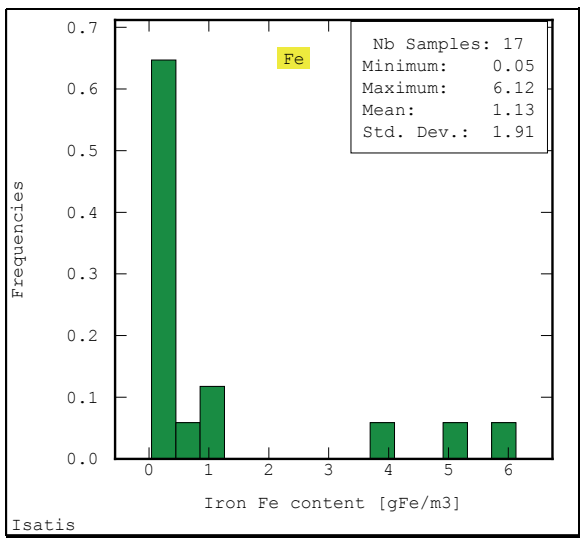

Fig. 15. Distribution histogram of Fe content $\left[\mathrm{g} \mathrm{Fe} / \mathrm{m}^{3}\right]$ in underground water in Kłodzko water intake area
Mn content

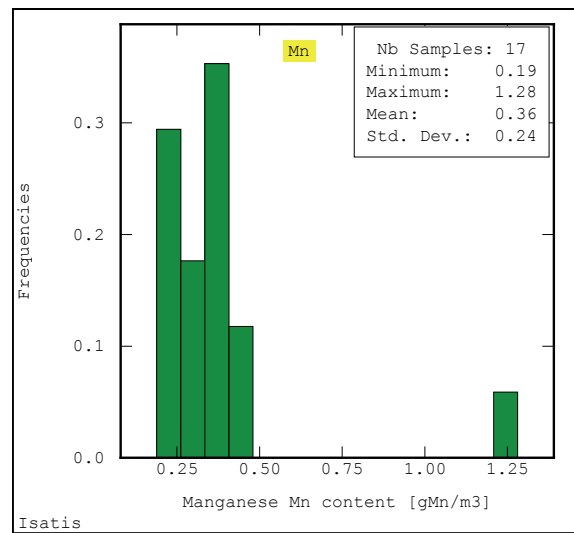

Fig. 16. Distribution histogram of Mn content $\left[\mathrm{g} \mathrm{Mn} / \mathrm{m}^{3}\right]$ in underground water in Kłodzko water intake area

$\mathrm{pH}$ potential

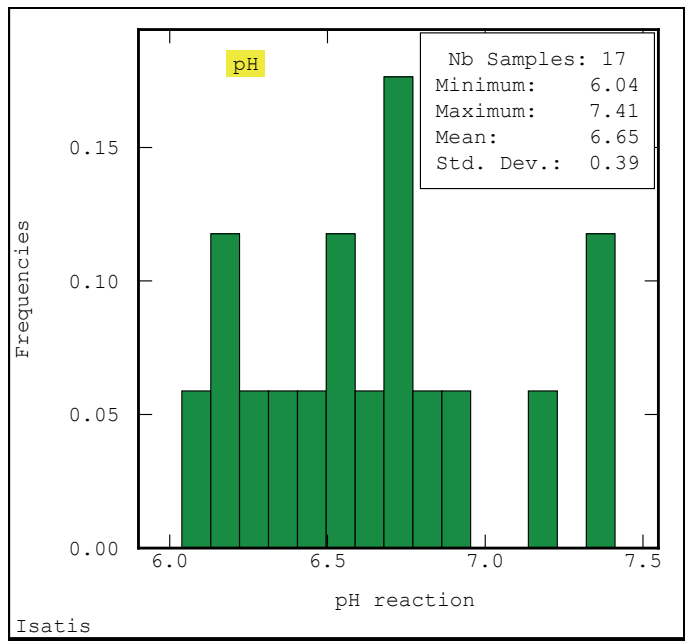

Fig. 17. Distribution histogram of $\mathrm{pH}$ of underground water 
in Kłodzko water intake area

Table 18

Skewness $g_{1}$ and kurtosis $g_{2}$ of distribution histograms of underground water parameters in Kłodzko water intake area

\begin{tabular}{|l|c|c|}
\hline \multicolumn{1}{|c|}{ Parameter analyzed } & $\begin{array}{c}\text { Skewness } \\
g_{1}\end{array}$ & Kurtosis \\
& 1.762 & 4.427 \\
\hline Fe content $\left[\mathrm{g} \mathrm{Fe}_{2} \mathrm{~m}^{3}\right]$ & 3.045 & 11.857 \\
\hline $\mathrm{Mn}$ content $\left[\mathrm{g} \mathrm{Mn} / \mathrm{m}^{3}\right]$ & 0.470 & 2.475 \\
\hline $\mathrm{pH}$ reaction & \\
\hline
\end{tabular}

The distribution histogram of $\mathrm{Mn}$ content shows the strongest positive skewness $\left(g_{1}\right)$ and slenderness $\left(g_{2}\right)$ (Fig. 16). A much weaker positive skewness $\left(g_{1}\right)$ characterizes the distribution histogram of Fe content (Fig. 15) (Table 18). The distribution histogram of Fe content is a single-side histogram (Fig. 15), the histogram of Mn histogram is two-modal (Fig. 16) and the histogram of $\mathrm{pH}$ potential has a multimodal character (Fig. 17).

\section{CONCLUSION}

The multidirectional spatial analyses of the quality parameters variability in the Kłodzko underground water intake area revealed certain regularities in the variation in water quality.

The average values of Fe and Mn content in the years 1977-1999 for the Kłodzko underground water intake area with 22 wells significantly exceed the standard values of the parameters. An analysis of the mean values of these parameters in the years mentioned shows random (incidental) fluctuations in $\mathrm{Fe}$ content and a tendency to periodical changes in Mn content and in oxidizing capacity.

The estimates of the quality parameters of the water taken from 14 wells located in the water intake area, concerning the maximal, average and minimal Fe and $\mathrm{Mn}$ content values, indicate significant exceedances of the standard values of these elements. The maximal ammonium ion $\mathrm{NH}_{4}^{+}$content in the water is close to its standard value. In the case of the other parameters analyzed, the statistics do not show any exceedance of the standard values.

The values of the variability coefficients $(V)$ of 8 water quality parameters indicate very high variation in $\mathrm{Fe}$ content and in nitrite anion $\mathrm{NO}_{3}^{-}$content. Also $\mathrm{Mn}$ content and ammonium ion $\mathrm{NH}_{4}^{+}$content (with identical values of coefficient $V$ ) show high variation. Low values of coefficients $V$ indicate slight variation in the temperature ${ }^{\circ} \mathrm{C}$ and $\mathrm{pH}$ potential of the water.

It has been found that taking or not taking into account the data on the quality pa- 
rameters of the collector siphon well has no effect on the estimates of the basic statistics. The means of the parameters are identical or the differences between them are statistically insignificant - minimal.

The estimates of the basic statistics of the underground water quality parameters for the Kłodzko water intake area, based on the data acquired from 14 wells as well as from the three new piezometers, indicate extremely high variation in Fe content, high or average variation in $\mathrm{Mn}$ content and very low variation in the $\mathrm{pH}$ reaction of the water.

In three piezometers installed in the underground water intake area, the Fe content and the Mn content were found to be considerably exceeded. The minimal value $X_{\min }$ and the maximal value $X_{\max }$ and the average values of $\mathrm{Fe}$ and $\mathrm{Mn}$ content in the water are very high. Variation coefficients $V$, calculated on the basis of the data acquired from the three piezometers, indicate low variation in Fe content and average variation in Mn content. It seems that drawing conclusions on the basis of such a small number of piezometers may lead to erroneous inferences about the degree of variation in $\mathrm{Fe}$ and $\mathrm{Mg}$ contents. Only if data from a larger number of wells are used in the analysis one will be able to reliably estimate the variation in the parameters considered.

\section{REFERENCES}

[1] Armstrong M., Basic Linear Geostatistics, Springer, Berlin 1998, 153 p.

[2] Armstrong M., Carignan J., Géostatistique Linéaire - Application au Domaine Minier, Les Presses de l'Ecole des Mines, Paris 1997, 115 p.

[3] Castore M., Cherubini C., Giasi C.I., Molinari M., The Application of Multivariable Geostatistical Analysis in the Study of Contaminated Sites, 2005.

[4] Chauvet P., Processing Data with a Spatial Support: Geostatistics and its Methods, Cahiers de Géostatistique 4, Paris: ENSMP, 1993. 57 p.

[5] ChilÈs J.P., Delfiner P., Geostatistics: Modeling Spatial Uncertainty, Second Edition, Wiley, N.Y. 2012, 734 p. (Wiley series in probability and statistics).

[6] Cinnirellaa S., Buttafuoco G., Irronea N., Stochastic analysis to assess the spatial distribution of groundwater nitrate concentrations in the Po catchment, (Italy) Elsevier, Sept. 2004.

[7] DĄBRowsKi S., Kraszewski K., PleCZyŃSKi J., Badania modelowe ujęcia wód podziemnych z utworów czwartorzędowych w rejonie Kłodzka, woj. watbrzyskie; Zlewnia: Odry (Nysy Kłodzkiej), Poznań, maj 1982, s. 13.

[8] Dokumentacja hydrogeologiczna zasobów wód infiltracyjnych z utworów czwartorzędowych z projektem na rozbudowe ujęcia wody dla m. Kłodzka, Przedsiębiorstwo Geologiczne, ul. Wierzbowa 15, Wrocław 1982.

[9] FAUCHEUX C., JEANNÉE N., Industrial experience feedback of a geostatistical estimation of contaminated soil volumes, Presented at Intersol 2011.

[10] Flipo N., JEANNÉE N. et al., Nitrates fate in a small basin: combined use of kriging and physicallybased model, 2005.

[11] GuASTALDi E., Geostatistical modelling of uncertainty for the risk analysis of contaminated sites, 2007.

[12] Isaaks E.H., Srivastava R.M., An Introduction to Applied Geostatistics, OUP, N.Y. 1989, 561 p.

[13] JEANNÉE N., Isatis applications for soil pollution mapping and risk assessment, Presented at Isatis 
Users Meeting, Geovariances, 2006.

[14] Jeannée N., Berckmans A., Wouters L., Chiles J.P., Assessing the Spatial Continuity of Low Permeability Media for Deep Waste Disposal, the Boom Clay Case - Sept. 2009, Presented at GLOBAL 2009.

[15] Jeannée N., Faucheux C., Bardou E., ORnstein P., Geostatistical modeling of ice content within the "Glacier Bonnard", (Switzerland) Spatial Data Methods for Environmental and Ecological Processes, 2nd edition, Sept. 2011.

[16] LaZARowicz K., Projekt koncepcyjny rozbudowy ujęcia wody dla miasta Kłodzka do 2030 roku, Praca dyplomowa magisterska (nr I - 15/ZD - 4/1/2009/2010), s. 88. Wydział Inżynierii Środowiska Politechniki Wrocławskiej, Promotor dr hab. inż. Andrzej Kotowski, prof. PWr.

[17] Matheron G., Estimating and Choosing - An Essay on Probability in Practice, Springer, Berlin $1989,141 \mathrm{p}$.

[18] Matheron G., The intrinsic random functions and their application, Adv. App. Prob., Vol. 5, 1973, 439-468.

[19] MĄDRALA M., Waloryzacja hydrogeochemiczna środowisk dolin rzecznych dla potrzeb eksploatacji wód podziemnych, Współczesne Problemy Hydrogeologii, Wrocław 2001, 357-364.

[20] Mari J.L., Porel G., 3D Seismic Imaging of a Near-Surface Heterogeneous Aquifer: A Case Study, Oil \& Gas Science and Technology, Rev. IFP, Nov. 2007.

[21] NAMYSŁOWSKA-WilczYŃSKA B., Geostatystyka - Teoria i Zastosowania, Oficyna Wydawnicza Politechniki Wrocławskiej, Wrocław 1996, s. 356.

[22] NAMYSŁOWSKA-WiLCZYŃSKA B., Model hydrogeochemiczny dla obszaru ujęć wody podziemnej $w$ Kłodzku, Raport Instytutu Geotechniki I Hydrotechniki Politechniki Wrocławskiej, serii SPR 1/2012, Wrocław, marzec 2012, s. 279.

[23] RENARD F., JEANNEE N., Estimating transmissivity fields and their influence on flow and transport: The case of Champagne mounts, Water Resources Research, Vol. 44, Nov. 2008.

[24] Wackernagel H., Multivariate Geostatistics: an Introduction with Applications, 2nd ed., Springer, Berlin 1998, $291 \mathrm{p}$. 